[Agr. Biol. Chem., Vol. 36, No. 8, p. 1335 1342, 1972]

\title{
Purification and Properties of $\alpha$-D-Galactosidase Produced by Corticium rolfsii
}

\author{
By Akira KaJI and Osamu YoshiHARA* \\ Department of Agricultural Chemistry, Kagawa University, \\ Miki-cho, Kagawa-ken
}

Received December 6, 1971

\begin{abstract}
An $\alpha$-D-galactosidase was purified from the culture filtrate of Corticium rolfsii IFO 6146 by a combination of QAE-Sephadex A-50 and SE-Sephadex C-50 chromatography. The purified enzyme was demonstrated to be free of other possibly interfering glycosidases and glycanases. The maximum activity of the enzyme towards $p$-nitrophenyl $\alpha$-D-galactopyranoside was found to be at $\mathrm{pH} 2.5$ to 4.5 , and the enzyme was fairly active at $\mathrm{pH} 1.1$ to 2.0 . The enzyme was stable over a pH range 4.0 to 7.0 at $5^{\circ} \mathrm{C}$ for $72 \mathrm{hr}$ and relatively unstable at $\mathrm{pH} 1.1$ to 2.0 as compared with endo-polygalacturonase, $\alpha$-L-arabinofuranosidase and $\beta$-D-galactosidase produced by $C$. rolfsii. The enzymic activity was completely inhibited by $\mathrm{Hg}^{2}-$ and $\mathrm{Ag}^{+}$ions, respectively. $K m$ values were determined to be $0.16 \times 10^{-3} \mathrm{M}$ for $p$-nitrophenyl $\alpha$-D-galactopyranoside and $0.26 \times 10^{-3} \mathrm{M}$ for 0 -nitrophenyl $\alpha$-D-galactopyranoside. The values of $V_{\mathrm{max}}$ were also determined to be $26.6 \mu$ moles and $28.6 \mu$ moles per min per $\mathrm{mg}$ for $p$ - and $o$-nitrophenyl $\alpha$-D-galactopyranoside, respectively.
\end{abstract}

A variety of micro-organisms has been reported to produce $\alpha$-D-galactosidase ( $\alpha$-Dgalactoside galactohydrolase, EC 3. 2. 1. 22) and the typical organisms have been shown to be Saccharomyces cerevisiae, ${ }^{1,2)}$ Aspergillus niger, ${ }^{3,41}$ Streptomyces olivaceus ${ }^{51}$ and Mortierella vinacea ${ }^{6,7)}$ Corticium rolfsii $\mathrm{K} 2^{81}$ was also found to be a good source of $\alpha$-galactosidase and to produce 27.5 times as much enzyme as $A$. niger ATCG 10577. The enzyme produced by $C$. rolfsii was shown to be optimal under acidic condition and tolerable at $\mathrm{pH}$ values 2 to 7 with crude enzyme preparation. ${ }^{81}$ The $\alpha$ galactosidases produced by $C$. rolfsii were also found to be separated into three components by the chromatography on QAE-Sephadex A$50{ }^{7,81}$ The purpose of the present publication is to describe the method for further purification and some properties of one purified component.

* Present address: Marukin Shoyu Research Laboratory, Marukin Shoyu \& Co. Ltd.

\section{MATERIALS AND METHODS}

Organism. The strain IFO 6146 of $C$. rolfsii was used throughout the present work, and was cultured by the method described in the previous paper. ${ }^{8}$

Purification of enzyme. The mycelium was removed by filtration and subsequent centrifugation, then $\left(\mathrm{NH}_{4}\right)_{2} \mathrm{SO}_{4}$ was added to the culture filtrate to 0.9 saturation. After the mixture had stood overnight, the resulting precipitate was collected by centrifugation and dissolved in deionized water. The solution was dialyzed for $24 \mathrm{hr}$ each, first against deionized water and then against $0.01 \mathrm{M}$ sodium phosphate buffer ( $\mathrm{pH}$ 7.5). The dialyzed solution was applied to a column of QAE-Sephadex A-50 which had been equilibrated with the same buffer ( $\mathrm{pH} 7.5)$. The enzyme was eluted by the step-wise addition of 0.1 and $0.2 \mathrm{M} \mathrm{NaCl}$, successively, with constant $0.01 \mathrm{M}$ sodium phosphate buffer ( $\mathrm{pH} 7.0$ ). Fractions rich in $\alpha$-galactosidase eluted by the buffer containing $0.1 \mathrm{M}$ $\mathrm{NaCl}$, were combined and dialyzed for $24 \mathrm{hr}$ against deionized water and for further $24 \mathrm{hr}$ against $0.04 \mathrm{M}$ citrate-phosphate buffer ( $\mathrm{pH} 3.3$ ). The enzyme solution was applied to a column of SE-Sephadex C-50 
which was previously equilibrated with the same buffer ( $\mathrm{pH}$ 3.3). The enzyme was eluted by the step-wise addition of $0.04 \mathrm{M}$ citrate-phosphate buffer, $\mathrm{pH} 3.3$, pH 3.7, and pH 4.1, successively. Fractions rich in $\alpha$-galactosidase, eluted at $\mathrm{pH} 4.1$, were collected, dialyzed for $24 \mathrm{hr}$ each, first against deionized water and then $0.01 \mathrm{M}$ sodium phosphate buffer ( $\mathrm{pH} 7.5$ ). The second chromatography on QAE-Sephadex A-50 was performed as described above. Fractions rich in $\alpha$-galactosidase were collected and dialyzed against $0.003 \mathrm{M}$ sodium phosphate buffer $(\mathrm{pH} 6.0)$ and subjected to the test of enzyme properties. The solution was also concentrated by lyophilization, and the concentrated solution was used for Disc electrophoresis.

Substrates and other chemicals. p-Nitrophenyl $\alpha$-Dgalactopyranoside was used as substrate throughout the present work and o-form was also used in the kinetic study. The former galactoside was purchased from Pierce Chemicals Comp., and the latter from Sigma Chemicals Comp. The other chemicals tested for substrate specificity or inhibitory effect were purchased as follows: $p$-nitrophenyl $\alpha$ - and $\beta$-Dglucopyranosides (Koch-Light Laboratories); $p$-nitrophenyl $\beta$-D-galactopyranoside (Sigma Chemicals Comp.); $p$-nitrophenyl $\beta$-D-xylopyranoside and $p$-nitrophenyl $\alpha$-L-fucopyranoside (Pierce Chemicals Comp.); $p$-nitrophenyl $N$-acetyl $\beta$-D-galactosaminide and $p$ nitrophenyl N-acetyl $\beta$-D-glucosaminide (Seikagaku Kogyo Comp.); phenyl $\beta$-L-arabinopyranoside (Ikagaku Sōgö Laboratories, Kyoto); melibiose, and stachyose (Sigma Chemicals Comp.); raffinose (E. Merk Comp.); $p$-chloromercuribenzoic acid sodium salt (Mann Research Laboratories).

Phenyl $\alpha$-L-arabinofuranoside was prepared according to the method reported by Börjeson $e t$ al.91 Acid soluble pectic acid was prepared by the method described in the previous paper.10\}

Enzyme assay. A reaction mixture containing 0.8 $\mathrm{ml}$ of $1.0 \mathrm{~mm} p$-nitrophenyl $\alpha$-D-galactopyranoside, $0.8 \mathrm{ml}$ of $0.1 \mathrm{M} \mathrm{HCl}$-sodium citrate buffer $(\mathrm{pH} \mathrm{2.5})$, $0.8 \mathrm{ml}$ of enzyme solution and two drops of toluene was incubated at $30^{\circ} \mathrm{C}$ for $30 \mathrm{~min}$. The reaction was stopped by the addition of $1 \mathrm{ml}$ of $0.1 \mathrm{M} \mathrm{Na}_{2} \mathrm{CO}_{3}$ to $1 \mathrm{ml}$ of reaction mixture. The $p$-nitrophenol released by the action of enzyme was determined by measuring the absorbance at $400 \mathrm{~m} \mu$ by a Hitachi spectrophotometer (model 139). One unit of $\alpha$-D-galactosidase was defined as the amount of enzyme which liberated $1 \mu$ mole of nitrophenol per min under the above condi- tions. The actions on the biological sugars were tested in a reaction mixture containing $1.0 \mathrm{ml}$ of $10 \mathrm{mM}$ substrate $(\mathrm{pH} 2.5), 3.0 \mathrm{ml}$ of $0.1 \mathrm{M} \mathrm{HCl}$-sodium citrate buffer ( $\mathrm{pH} 2.5$ ), $1.0 \mathrm{ml}$ of enzyme solution, $0.25 \mathrm{ml}$ of deionized water and 2 drops of toluene. The galactose released was determined by the method of Nelson-Somogyi.11,12i

Electrophoresis of enzyme. Electrophoresis was carried out on polyacrylamide gel according to the procedure described by Davis. ${ }^{13}$

Determination of protein. The amount of protein in the enzyme solution was calculated from the absorbance at $280 \mathrm{~m} \mu$ with crystalline $\alpha$-L-arabinofuranosidase which had been prepared from culture fluid of $A$. niger in our laboratory. 141

\section{RESULTS}

\section{Purification of enzyme}

The crude enzyme solution, precipitated with $\left(\mathrm{NH}_{4}\right)_{2} \mathrm{SO}_{4}$ and dialyzed against deionized water and $0.01 \mathrm{M}$ sodium phosphate buffer ( $\mathrm{pH} 7.5$ ) before hand, was subjected to a column of QAE-Sephadex A-50. As already described in the previous paper, ${ }^{81}$ the activity of $\alpha$-galactosidase was recovered in three peaks, I, II and III. As shown in Fig. 1, most of the activity was eluted in peak I with $0.01 \mathrm{M}$ sodium phosphate buffer ( $\mathrm{pH} 7.0)$ containing $0.1 \mathrm{M} \mathrm{NaCl}$, and active fractions were combined and dialyzed. The dialyzed solution was applied to a column of SESephadex C-50. As shown in Fig. 2, active fractions eluted with $0.04 \mathrm{M}$ citrate-phosphate buffer ( $\mathrm{pH} 4.1$ ) were combined and dialyzed. The enzyme solution was subjected to the second column chromatography on QAESephadex A-50. The result shown in Fig. 3 indicated that the activity curve of $\alpha$-galactosidase was parallel to the amount of protein.

The results of the over all purification procedures are summarized in Table $I$ and show the 95-fold increase in specific activity. For the purpose of electrophoretic analysis, the enzyme solution was dialyzed against 


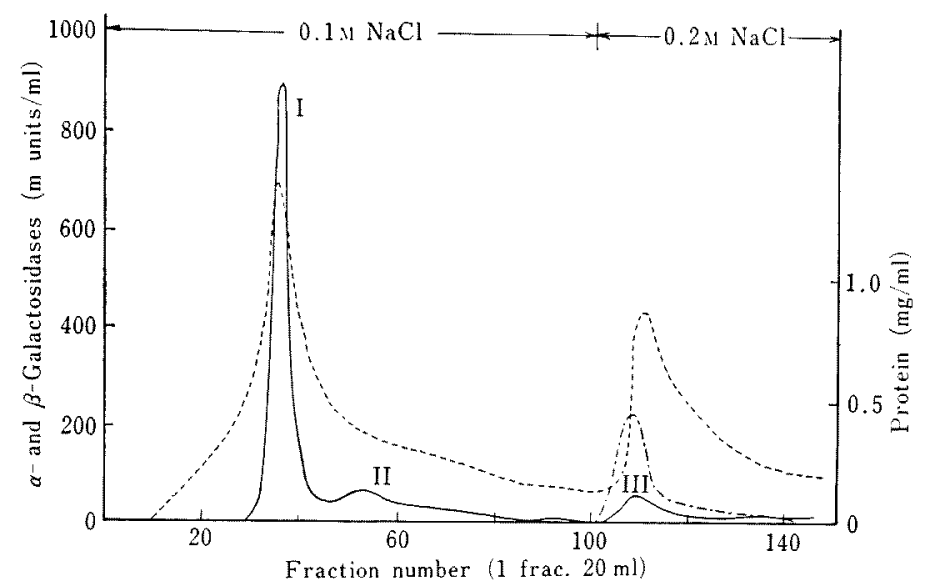

FIG. 1. Chromatography on QAE-Sephadex A-50 (I).

QAE-Sephadex A-50 was equilibrated with $0.01 \mathrm{M}$ sodium phosphate buffer (pH 7.5) and packed in a column, $2.5 \mathrm{~cm} \times 60 \mathrm{~cm}$. The enzyme solution, $380 \mathrm{ml}$ containing $1.9 \mathrm{~g}$ protein or 247 units of $\alpha$-galactosidase, was poured onto the column. The enzyme was eluted with a step-wise addition of 0.1 and $0.2 \mathrm{M}$ $\mathrm{TaCl}$, successibly, in $0.01 \mathrm{M}$ sodium phosphate bufier $(\mathrm{pH} 7.0)$. Fractions $32 \sim 39$ were combined. - $\alpha$-galactosidase activity; - - $\beta$-galactosidase activity; -----, protein.

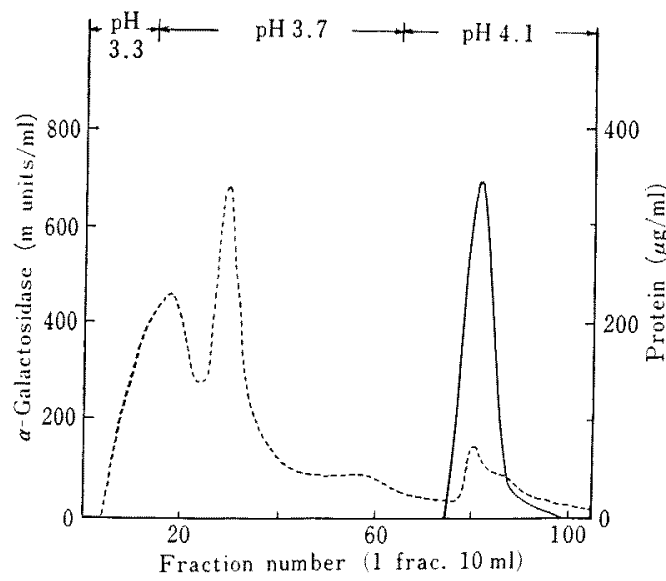

Fig. 2. Chromatography on SE-Sephadex C-50.

SE-Sephadex C-50 was equilibrated with $0.04 \mathrm{M}$ citrate-phosphate buffer ( $\mathrm{pH} 3.3$ ) and packed in a column, $2.5 \mathrm{~cm} \times 40 \mathrm{~cm}$. The enzyme solution, $160 \mathrm{ml}$ containing $205 \mathrm{mg}$ of protein or 96 units of $\alpha$-galactosidase, was poured onto the column, which was washed with a step-wise addition of the same buffer having $\mathrm{pH} 3.3, \mathrm{pH} 3.7$ and $\mathrm{pH}$ 4.1 , successibly. Fractions $76 \sim 86$ were combined. - enzyme activity; ......, protein.

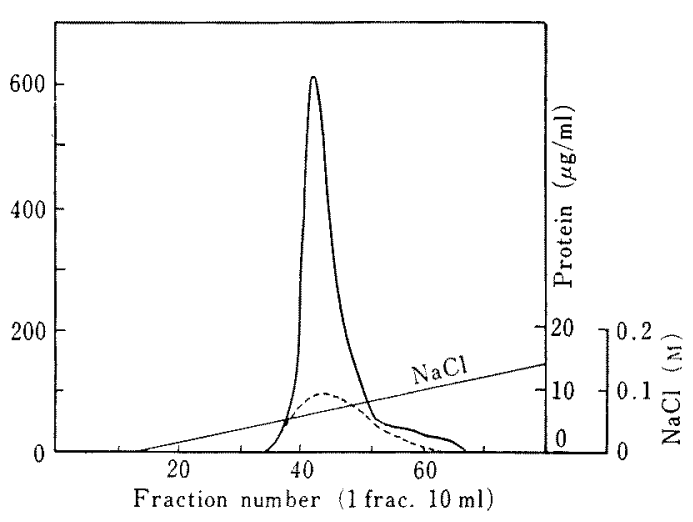

FIG. 3. Chromatography on QAE-Sephadex A-50 (II).

QAE-Sephadex A-50 was equilibrated with $0.1 \mathrm{M}$ sodium phosphate buffer ( $\mathrm{pH} 7.5$ ) and packed in a column, $2.0 \mathrm{~cm} \times 35 \mathrm{~cm}$. The enzyme solution, $110 \mathrm{ml}$ containing $6.8 \mathrm{mg}$ protein or 60.5 units of $\alpha$ galactosidase, was poured onto the column. The enzyme was eluted with a linear gradient of $0 \sim 0.2 \mathrm{M} \mathrm{NaCl}$ in $0.01 \mathrm{M}$ sodium phosphate buffer (pH 7.0). Fractions $40 \sim 48$ were combined. enzyme activity; -....., protein. 
Table I. Purification of $\alpha$-Galactosidase

\begin{tabular}{lccccc}
\hline Step & $\begin{array}{c}\text { Vol } \\
(\mathrm{ml})\end{array}$ & $\begin{array}{c}\text { Total } \\
\text { protein } \\
(\mathrm{mg})\end{array}$ & $\begin{array}{c}\text { Total } \\
\text { (units) }\end{array}$ & $\begin{array}{c}\text { Yield } \\
\left(\mathbf{O}^{\circ}\right)\end{array}$ & $\begin{array}{c}\text { Specific } \\
\text { activity } \\
\text { (units/mg) }\end{array}$ \\
\hline $\begin{array}{c}\left(\mathrm{NH}_{4}\right)_{2} \mathrm{SO}_{4} \\
(0.4 \sim 0.7 \text { sat. })\end{array}$ & 380 & 1900 & 247 & 100 & 0.13 \\
$\begin{array}{c}\text { QAE-Sephadex } \\
\text { A-50 (I) }\end{array}$ & 160 & 205 & 96 & 38.9 & 0.47 \\
$\begin{array}{c}\text { SE-Sephadex } \\
\text { C-50 }\end{array}$ & 110 & 6.8 & 60.5 & 24.5 & 8.90 \\
$\begin{array}{c}\text { QAE-Sephadex } \\
\text { A-50 (II) }\end{array}$ & 90 & 2.7 & 33.3 & 13.5 & 12.30 \\
\hline
\end{tabular}

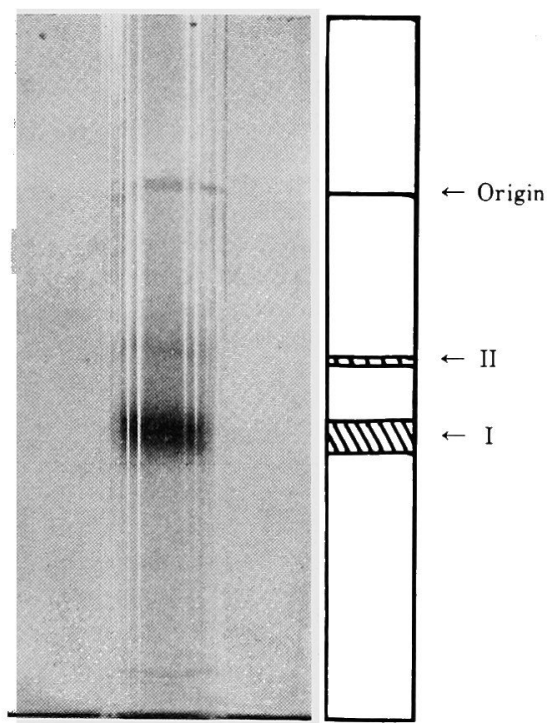

FIG. 4. Disc Electrophoresis of $\alpha$-Galactosidase on Polyacrylamide Gel.

The purified enzyme solution containing $90 \mu \mathrm{g}$ of protein was layered on a column of $7 \%_{0}^{\circ}$ polyacrylamide gel and allowed to migrate in Trisglycine buffer $(\mathrm{pH} \mathrm{8.3)}$ for $3 \mathrm{hr}$. Protein was stained with amido black $10 \mathrm{~B}$.

$0.003 \mathrm{M}$ sodium phosphate buffer $(\mathrm{pH} 6.0)$ and lyophilized for $5 \mathrm{hr}$. As shown in Fig. 4, the purified enzyme preparation was demonstrated to be almost one component indicated by band I but a faint band II was also detected besides the main enzyme protein.

\section{Enzymic properties}

Effect of enzyme concentration. The amount of $p$-nitrophenol produced was a linear function of enzyme concentration up to $3.3 \mu \mathrm{g}$ protein per $\mathrm{ml}$ of reaction medium under the conditions mentioned above.

Effect of pH activity of enzyme. The effect of $\mathrm{pH}$ on the activity of purified enzyme is shown in Fig. 5. The optimum range of $\mathrm{pH}$

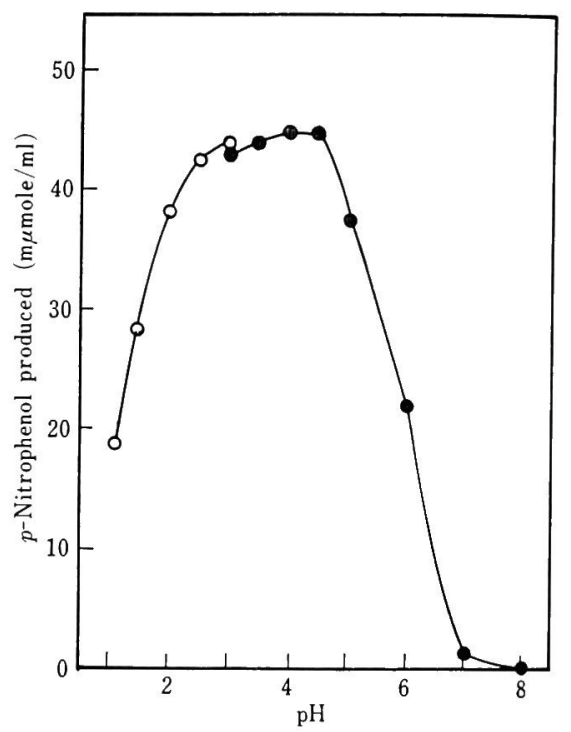

FIG. 5. Effect of $\mathrm{pH}$ on Activity of $\alpha$-Galactosidase.

A reaction mixture containing $0.8 \mathrm{ml}$ of $1.0 \mathrm{~mm}$ $p$-nitrophenyl $a$-D-galactopyranoside, $0.8 \mathrm{ml}$ of buffer and $0.8 \mathrm{ml}$ of enzyme solution $(4.4 \mathrm{~m}$ units per $\mathrm{ml}$ ) was incubated at $30^{\circ} \mathrm{C}$ for $30 \mathrm{~min} . \quad 0.1 \mathrm{M}$ HCl-sodium citrate buffer was used for $\mathrm{pH} 1.1$ to 3.0; $0.1 \mathrm{M}$ sodium citrate- $0.2 \mathrm{M}$ sodium phosphate buffer for $\mathrm{pH} 3.0$ to 8.0 .

values was 2.5 to 4.5 and the enzyme was fairly active at $\mathrm{pH} 1.5$ to 2.0 . The purified $\alpha$-galactosidase was still active at very low $\mathrm{pH}$ value of 1.1 .

Effect of pH on stability of enzyme. Stability of purified $\alpha$-galactosidase at various $\mathrm{pH}$ values and $5^{\circ} \mathrm{C}$ for $72 \mathrm{hr}$ was examined using $0.1 \mathrm{M} \mathrm{HCl}$-sodium citrate buffer for $\mathrm{pH} 1.1$ to 


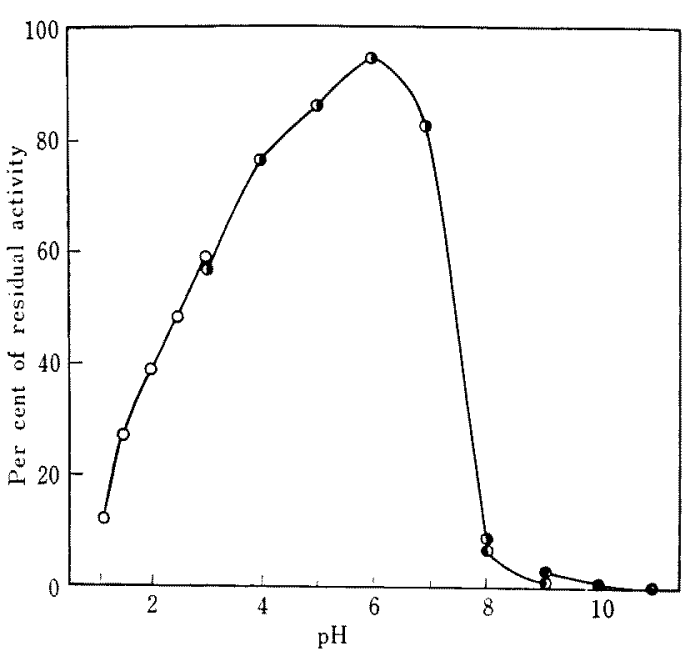

(I)

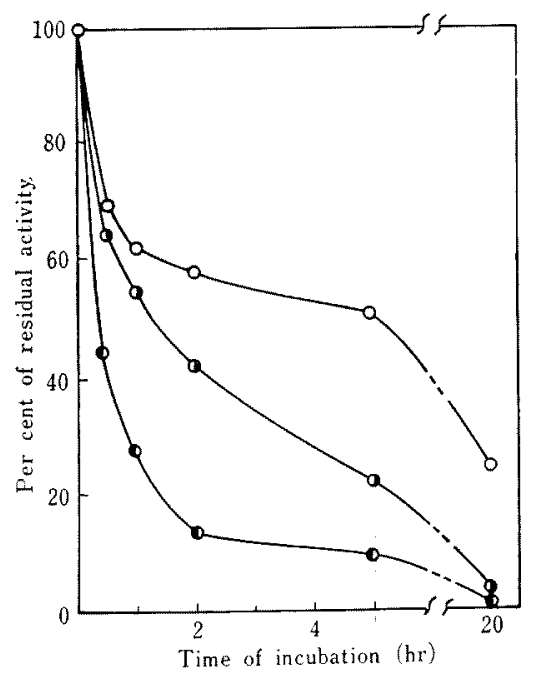

(II)

FIG. 6. Effect of $\mathrm{pH}$ on Stability of a-Galactosidase.

(I) At $5^{\circ} \mathrm{C}$. One $\mathrm{ml}$ of enzyme solution $(10 \mathrm{~m}$ units) and $1.0 \mathrm{ml}$ of each buffer were used for acid stability. Each mixture was allowed to stand at $5^{\circ} \mathrm{C}$ for $72 \mathrm{hr}$. The procedure was described in the text. Residual activity was represented as per cent of untreated enzyme solution.

(II) At $30^{\circ} \mathrm{C}$. Each mixture was allowed to stand at $30^{\circ} \mathrm{C}, 17.2 \mathrm{~m}$ units of enzyme was used.
$3.0,0.1 \mathrm{M}$ sodium citrate- $0.2 \mathrm{M}$ sodium phosphate buffer for $\mathrm{pH} 3.0$ to $8.0,0.2 \mathrm{M}$ Tris $-0.1 \mathrm{M}$ $\mathrm{HCl}$ buffer for $\mathrm{pH} 8.0$ to 9.0 and $0.05 \mathrm{M}$ $\mathrm{Na}_{2} \mathrm{CO}_{3}-0.1 \mathrm{M} \mathrm{NaHCO}_{3}$ buffer for $\mathrm{pH} 9.0$ to 11.0. One milliliter of the purified enzyme solution ( $\mathrm{pH} 2.5$ ) containing $10 \mathrm{~m}$ units of enzyme was mixed with $1 \mathrm{ml}$ of each buffer. Toluene was added to the mixture and the solution was kept at $5^{\circ} \mathrm{C}$ for $72 \mathrm{hr}$. After incubation, the $\mathrm{pH}$ of each mixture was adjusted to 2.5 and deionized water was added to bring each solution to the same volume; $4 \mathrm{ml}$. The enzyme activity was then determined by the method mentioned above. The result shown in Fig. 6(I) indicated that purified $\alpha$-galactosidase was relatively stable at $\mathrm{pH} 4.0$ to 7.0 .

Stability of the purified enzyme at low $\mathrm{pH}$ values and $30^{\circ} \mathrm{C}$ for $30 \mathrm{~min}$ to $20 \mathrm{hr}$ was also examined using $0.1 \mathrm{M}$ HCl-sodium citrate buffer. The amount of enzyme used here was $17.2 \mathrm{~m}$ units and the procedure was the same as described above. The temperature of incubation was adjusted to $30^{\circ} \mathrm{C}$ in place of low temperature, $5^{\circ} \mathrm{C}$. As shown in Fig. 6 (II), the purified enzyme was inactivated after $20 \mathrm{hr}$ of incubation at $\mathrm{pH} 1.5$ to 2.0, and $75 \%$ of enzyme activity was lost after $20 \mathrm{hr}$ of incubation at $\mathrm{pH} 2.5$.

These results evidently demonstrate that the stability of $\alpha$-galactosidase at low $\mathrm{pH}$ is a lesser degree than that of $\alpha$-L-arabinofuranosidase or endopolygalacturonase produced by $C$.rolfsii which is characteristic of later enzyme.

Action of $\alpha$-galactosidase on various galactosides. The various kinds of synthetic glycosides listed in Table II were examined with the purified enzyme solution and the highly purified $\alpha$ galactosidase from $C$. rolfsii was demonstrated to have no enzymic activity on these substrates except $p$-nitrophenyl $\alpha$-D-galactopyranoside. The various kinds of biological sugars were also tested for the action of purified enzyme and the clear activity was demonstrated on melibiose, raffinose and stachyose, respectively. 
Table II. ACtion of $\alpha$-Galactosidase on Various Kinds of Glycosides.

\begin{tabular}{|c|c|c|c|}
\hline Glycoside & $\begin{array}{l}\text { Concentration of enzyme } \\
\text { (m units } / \mathrm{ml} \text { of reaction } \\
\text { mixture) }\end{array}$ & $\begin{array}{l}\text { Incubation time } \\
\text { (hr) }\end{array}$ & $\begin{array}{l}p \text {-Nitrophenol or } \\
\text { sugar produced }\end{array}$ \\
\hline$p$-Nitrophenyl $\alpha$-D-galactopyranoside & 7.0 & 0.5 & $\begin{array}{l}70 \text { ( } \mathrm{m} \mu \mathrm{mole} / \mathrm{ml} \mathrm{of} \\
\text { reaction mixture) }\end{array}$ \\
\hline$p$-Nitrophenyl $\beta$-D-galactopyranoside & 7.0 & 5 & 0 \\
\hline$p$-Nitrophenyl $N$-acetyl $\beta$-D-galactosaminide & 7.0 & 5 & 0 \\
\hline$p$-Nitrophenyl N-acetyl $\beta$-D-glucosaminide & 7.0 & 5 & 0 \\
\hline$p$-Nitrophenyl $\alpha$-D-glucopyranoside & 7.0 & 5 & 0 \\
\hline$p$-Nitrophenyl $\beta$-D-glucopyranoside & 7.0 & 5 & 0 \\
\hline$p$-Nitrophenyl $\alpha$-L-fucopyranoside & 7.0 & 5 & 0 \\
\hline$p$-Nitrophenyl $\beta$-D-xylopyranoside & 7.0 & 5 & 0 \\
\hline Phenyl $\alpha$-L-arabinofuranoside & 7.0 & 5 & 0 \\
\hline Phenyl $\beta$-L-arabinopyranoside & 7.0 & 5 & 0 \\
\hline Acid soluble pectic acidal & 4.0 & 5 & $0(\mu \mathrm{g} / \mathrm{ml})$ \\
\hline Cellobiose & 80.0 & 5 & 0 \\
\hline Gentibiose & 80.0 & 5 & 0 \\
\hline Lactose & 80.0 & 5 & 0 \\
\hline Maltose & 80.0 & 5 & 0 \\
\hline Sucrose & 80.0 & 5 & 0 \\
\hline Trehalose & 80.0 & 5 & 0 \\
\hline Melibiose & 80.0 & 5 & 16 \\
\hline Raffinose & 80.0 & 5 & 170 \\
\hline Stachyose & 80.0 & 5 & 20 \\
\hline Pectic acidbs & 4.0 & 5 & $\begin{array}{l}0 \text { (viscosity } \\
\text { decrease \%) }\end{array}$ \\
\hline
\end{tabular}

a) Activity was determined by increase of reducing value at $\mathrm{pH} 2.5$ and 4.0 .10 )

$b$ : Activity was determined by measuring viscosity decrease at $\mathrm{pH} 4.0 .101$

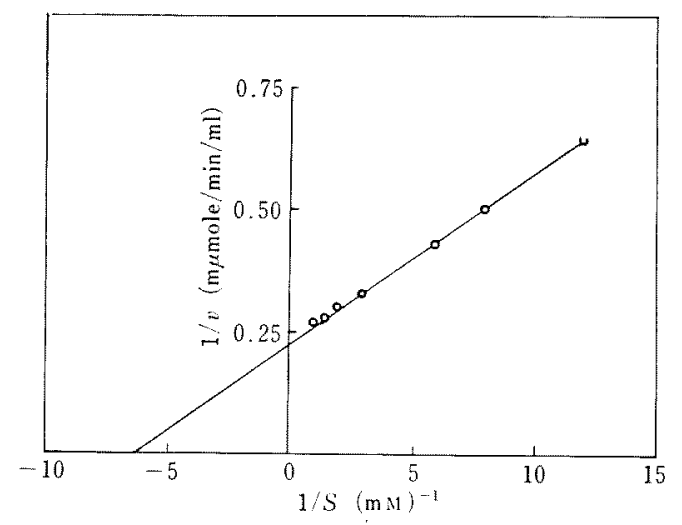

(I)

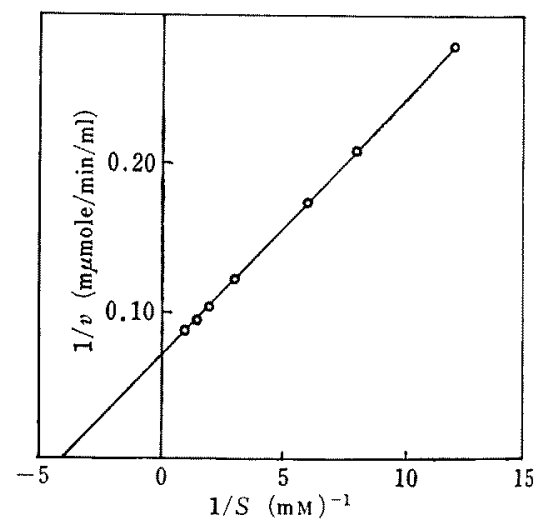

(II)

FIG. 7. Lineweaver-Burk Plots for $C$. rolfsii $\alpha$-Galactosidase.

Assays were carried out at $30^{\circ} \mathrm{C}$ and $\mathrm{pH} 2.5$ for $10 \mathrm{~min}$. Concentration of enzyme protein was $0.17 \mu \mathrm{g}$ (I) and $0.50 \mu \mathrm{g}$ (II), respectively.

(I) $p$-Nitrophenyl $\alpha$-D-galactopyranoside was used as substrate.

(II) $o$-Nitrophenyl $\alpha$-D-galactopyranoside was used as substrate. 
The enzymic product was paperchromatographically confirmed to be D-galactose in each test.

Michaelis constants were determined to be $0.16 \times 10^{-3} \mathrm{M}$ for $p$-nitrophenyl $\alpha$-D-galactopyranoside and $0.26 \times 10^{-3} \mathrm{M}$ for o-nitrophenyl $\alpha$-D-galactopyranoside. The values of $V_{\max }$ were also calculated to be $26.6 \mu$ moles for $p$-nitrophenyl $\alpha$-D-galactopyranoside and $28.6 \mu$ moles per min per $\mathrm{mg}$ for o-nitrophenyl $\alpha-\mathrm{D}-$ galactopyranoside, respectively. These constants were determined by the method of Lineweaver and Burk. ${ }^{15}$ The results are shown in Fig. 7(I) and (II).

Inhibition studies. For studying the inhibitory effect of salts on the enzymic action, $0.8 \mathrm{ml}$ of enzyme solution containing $4.4 \mathrm{~m}$ units of enzyme, $0.4 \mathrm{ml}$ of $0.1 \mathrm{M}$ sodium citrate- $0.2 \mathrm{M}$ sodium phosphate buffer $(\mathrm{pH} 4.0)$ and $0.4 \mathrm{ml}$ of salt solution were mixed and the mixture was allowed to stand at $30^{\circ} \mathrm{C}$ for $20 \mathrm{~min}$, to which was added $0.8 \mathrm{ml}$ of $1.0 \mathrm{~mm}$ $p$-nitrophenyl $\alpha$-D-galactopyranoside solution $(\mathrm{pH} 4.0)$ and the reaction was carried out at

TABLE III. EFFECT OF SALT ON ENZYMIC ACTION

\begin{tabular}{|c|c|c|}
\hline Salt & $\begin{array}{l}\text { Concentration } \\
\text { (mM) }\end{array}$ & $\begin{array}{c}\text { Relative activity } \\
(0)\end{array}$ \\
\hline $\mathrm{MnSO}_{4}$ & 1 & 100 \\
\hline $\mathrm{Fe}_{2}\left(\mathrm{SO}_{4}\right)_{2}$ & 1 & 90 \\
\hline $\mathrm{FeSO}_{4}$ & 1 & 95 \\
\hline $\mathrm{CuSO}_{4}$ & 1 & 100 \\
\hline $\mathrm{ZnSO}_{4}$ & 1 & 100 \\
\hline Mercuric acetate & 1 & 0 \\
\hline Calcium acetate & 1 & 100 \\
\hline $\mathrm{CoCl}_{2}$ & 1 & 100 \\
\hline $\mathrm{AgNO}_{3}$ & 1 & 0 \\
\hline $\mathrm{NaCl}$ & 100 & 102 \\
\hline $\mathrm{NaCl}$ & 10 & 101 \\
\hline $\mathrm{KCl}$ & 10 & 100 \\
\hline$p \mathrm{CMB}^{a}$ & $10^{-2}$ & 100 \\
\hline $\operatorname{EDTA}^{b !}$ & 1 & 100 \\
\hline None & & 100 \\
\hline
\end{tabular}

a) $p$-Chloromercuribenzoate

b) Ethylenediamine tetraacetate $30^{\circ} \mathrm{C}$ for $30 \mathrm{~min}$. The enzymic activity was assayed and represented in Table III as per cent of the activity of mixture without salt. Among various metal ions tested, $\mathrm{Hg}^{2+}$ and $\mathrm{Ag}^{+}$were found to be potent inhibitor.

\section{DISGUSSION}

The presence of $\alpha$-galactosidase has been reported in a variety of micro-organisms, animals and higher plants. Various microorganisms have been shown to produce $\alpha$ galactosidase having acidic $\mathrm{pH}$ optimum; $\mathrm{pH} 4.0$ for $A$. niger," 5.2 for $S$. olivaceus, 4.0 to 6.0 , and 3.0 to 5.0 for $M$. vinacea. ${ }^{7}$ In 1969, one of the authors, Kaji, and Ichimi ${ }^{81}$ have reported that $C$. rolfsii strain $\mathrm{K} 2$ produces acid $\alpha$ - and $\beta$-galactosidases which are shown to be stable and optimally active under acidic conditions using crude enzyme preparation. The results from the present work demonstrate that the highly purified $a$-galactosidase of $C$. rolfsii is most active at $\mathrm{pH} 2.5$ to 4.5 towards $p$-nitrophenyl $\alpha$-Dgalactopyranoside and fairly active at lower $\mathrm{pH}$ values of 1.1 to 2.0 . Generally speaking, pH curve of enzyme have a clear peak. On the contrary, the activity curve of this $\alpha$ galactosidase was shown to be rather flat between $\mathrm{pH} 2.5$ and 4.5. The results also show that the highly purified $\alpha$-galactosidase from $C$. rolfsii is stable over a $\mathrm{pH}$ range, 4 to 7 , but less stable at $\mathrm{pH} 1.1$ to 2.0 as compared with the other acid glycosidases of $C$. rolfsii.

C. rolfsii is a oxalate-forming basidiomycete and the acidity of the culture fluid drops from $\mathrm{pH} 5.4$ to $2.0 \sim 2.2$ because of the production of oxalic acid. It is reasonable that this fungus produces acid glycosidases, glycanases and acid proteinase which are active at low $\mathrm{pH}$ and tolerable to hydrogen ions. These characters are able to be indicated not only in $\alpha$-galactosidase but also $\alpha$-L-arabinofuranosidase, ${ }^{16,17)} \beta$-D-galactosidase, ${ }^{8,18}$ endopolygalacturonase $^{109}$ and $\beta-1,3-D$-glucanase. ${ }^{19}$ 
All of these enzymes have been already purified and their properties have been reported in the previous reports.

However, the degrees of activity at low $\mathrm{pH}$ and acid tolerance are found to vary among these enzymes as detailed in presented results. Endo-polygalactosidase, $\alpha$-L-arabinofuranosidase and $\beta$-D-galactosidase are most active at very low $\mathrm{pH}, 1.5$ to 2.5 , and $\beta-1,3-\mathrm{D}$-glucanase and $\alpha$-D-galactosidase are active at higher $\mathrm{pH}$ values; e.g. the former is most active at $\mathrm{pH} 3.0$ to 5.5 and the latter at $\mathrm{pH}$ 2.5 to 4.5 .

Regard with acid tolerance, the stability of $\alpha$-galactosidase is lower than the other glycosidase produced by $C$. rolfsii. Evidently, the purified $\alpha$-galactosidase lost 64,0 of its activity at $\mathrm{pH} 2.0$ at $5^{\circ} \mathrm{C}$ for $72 \mathrm{hr}$, the purified $\alpha-\mathrm{L}-$ arabinofuranosidase ${ }^{167}$ lost $17 \%$ under the same conditions, $\beta$-galactosidase in crude state ${ }^{87}$ lost $6 \%$ at pH 2.0 at $2{ }^{\circ} \mathrm{C}$ for $72 \mathrm{hr}$, and the purified endo-polygalacturonase ${ }^{101}$ lost $6.5 \%$ at $\mathrm{pH} 1.5$ and $20^{\circ} \mathrm{C}$ for $72 \mathrm{hr}$, respectively.

However, the highly purified $\alpha$-galactosidase from $C$. rolfsii was demonstrated to be still active at $\mathrm{pH} 1.1$, and three enzymes mentioned above except $\beta$-1, 3-D-glucanase were also active at the same $\mathrm{pH}$ value. It is surprising that various enzymes produced by $C$. rolfsii have clear activity under strong acidic condition in which ordinary living organisms are not able to survive without being specially protected from hydrogen ions. It is concluded that $\alpha$ galactosidase purified in the present work belongs to acid glycosidase and it is called acid $\alpha$-D-galactosidase.
Acknowledgement. We thank Miss T. Ichimi for her help in the preliminary work.

\section{REFERENCES}

1) A. Bau, Chem. Ztg., 19, 1873 (1895).

2) E. Fischer and P. Linder, Ber, 28, 3034 (1895).

3) E. Hofmann, Biochem. Z., 273, 198 (1934).

4) Om P. Bahl and K. M. L. Agrawal, J. Biol. Chem., 244, 2970 (1969).

5) H. Suzuki, Y. Ozawa and O. Tanabe, Rep. Ferment. Res. Inst., No. 34, 51 (1968).

6) H. Suzuki, Y. Ozawa, H. Ohta and H. Yoshida, Agr. Biol. Chem., 33, 506 (1969).

7) H. Suzuki, Su-Chen Li and Yu-Teh Li, J. Biol. Chem., 245, 781 (1970).

8) A. Kaji and T. Ichimi, Appl. Microbiol,, 18, 1036 (1969).

9) H. Börjeson, P. Jerkeman and B. Lindberg, Acta Chem. Scan., 171705 (1963).

10) A. Kaji and T. Okada, Arch. Biochem. Biophys, 131, 203 (1969).

11) N. Nelson, J. Biol Chem., 153, 375 (1944).

12) M. Somogyi, ibid., 160, $6 \mathrm{l}$ (1945); 195, 19 (1952).

13) B. J. Davis, Ann. N. Y. Acad. Sci., 121, Art. 2, 404 (1964).

14) A. Kaji and K. Tagawa, Biochim. Biophys. Acta, 207, 456 (1970).

15) H. Lineweaver and D. Burk, J.Am. Chim. Soc,, 56, 658 (1934).

16) A. Kaji, O. Yoshihara, Appl. Microbiol., 17, 910 (1969).

17) A. Kaji and O. Yoshihara, Biochim. Biophys. Acta, 250, 367 (1971).

18) A. Kaji, M. Sato, N. Shinmyo and H. Miyasaka, Abstr. Ann. Meeting, Agr. Chem. Soc. Japan, April, 1970, Page 246.

19) A. Kaji, T. Ohsaki and O. Yoshihara, J. Agr. Chem. Soc. Japan, 45, 278 (1971). 